\title{
Komunikasi Pendidikan Guru Madrasah Ibtidaiyah dalam Jaringan (DARING)
}

\author{
H. Abd Rahim Mansyur \\ Dosen Tetap Universitas Muslim Indonesia \\ abdrahimmansyur.umi@gmail.com
}

\begin{abstract}
Abstrak
Tulisan ini mengulas tentang komunikasi pendidikan, khususnya bagi guru Madrasah Ibtidaiyah (MI) Dalam Jaringan (Daring). Saat ini, pembelajaran sepenuhnya dilakukan melalui daring sehingga komunikasi yang dibangun oleh guru sangat menentukan keberhasilan pembelajaran. Hasil kajian ini menyimpulkan bahwa Guru sebagai salah satu komunikator dalam komunikasi sangat menentukan keberhasilan pembelajaran. Di tengah pandemik, komunikasi pendidikan sangat penting sebagai instrumen satu-satunya dalam pembelajaran daring. Dengan demikian, pembelajaran di tengah pandemik sangat ditentukan oleh pola komunikais guru dalam pembelajaran. Guru perlu memiliki kemampuan komunikasi yang mumpuni melalui pendalaman materi komunikasi pendidikan dengan mempelajari hakikat komunikasi pendidikan, guru perlu memahami fungsi dan unsur komunikasi pendidikan. Selain itu, sangat penting pula bagi guru memahami kedudukannya dalam konteks komunikasi pendidikan untuk memaksimalkan pembelajaran. Guru memainkan peran komunikasi secara efektif melalui banyak peran yang meliputi perannya sebagai pembicara, sebagai moderator dalam pembelajaran., sebagai pembimbing untuk menuntun siswa, dan berperan sebagai manajer karena guru menjadi pengelola atau organisator seluruh proses pembelajaran.
\end{abstract}

\section{Kata Kunci: Komunikasi Pendidikan, Guru MI}

\section{Pendahuluan}

Salah satu dinamika yang menarik diamati selama masa Covid-19 adalah komunikasi pendidikan guru Madrasah Ibtidaiyah yang dilakukan dalam pembelajaran melalui saluran-saluran dalam jaringan (daring). Banyak pengamat menegaskan bahwa siklus pandemik ini akan terus berlanjut sehingga sangat penting bagi guru memaksimalkan komunikasi pendidikan dalam pembelajaran.

Komunikasi pendidikan merupakan salah satu aspek kunci dalam proses pembelajaran. Dalam proses pembelajaran terbangun komunikasi secara intens antara guru dengan siswa dalam upaya transfer ilmu pengetahuan. Saat ini komunikasi guru mendapatkan tantangan yang luar biasa karena intensitas komunikasi dalam pembelajaran ini terjalin secara virtual atau dalam jaringan (daring).

Guru dan siswa dalam komunikasi pendidikan merupakan dua komponen yang saling berelasi. Relasi ini terbangun melalui kegiatan pembelajaran sebagai suatu proses bagi guru memberikan ruang bagi siswa mengembangkan potensi dirinya dalam pembelajaran. Tentunya pemberian ruang ini diisi dengan komunikasi yang intens, persuasif, dan mencerahkan.

Proses pembelajaran yang dilakukan kemudian melahirkan semacam simbiosis mutualisme, termasuk pada aspek komunikasi yang terjalin saling memberikan tukar informasi melalui bahasa yang digunakan. Guru yang kurang memiliki komponen komunikasi pendidikan yang memadai akan gagal membangun simbiosisi mutualisme komunikasi dengan siswanya dalam pembelajaran maupun di lingkungan sekolah. Oleh karena itu, dibutuhkan interaksi yang dijalinkan oleh komunikasi yang dapat memberikan kenyamanan kepada siswa karena guru secara efektif harus melampui komunikasi dengan siswa sehingga tidak sekedar mengetahui secara parsial masalah-masalah siswa yang hanya bersifat permukaan.

Guru membutuhkan wawasan yang mumpuni dalam mengemban tugasnya menghadapi dinamika pembelajaran siswa yang semakin kompleks. Guru sangatlah dituntut profesional sehingga membutuh wawasan tersebut utamanya tentang proses pembelajaran secara utuh karena narasi tentang pembelajaran sudah harus dibangun secara imajiner dalam pemikiran seorang guru. Apalagi di tengah tantangan pandemik seperti saat ini, guru harus memiliki visi jauh ke depan sehingga mampu melakukan pemetaan potensi masalah yang dapat menggangu pembelajaran siswa. 
Sanjaya (2006) mengemukakan bahwa faktor guru menjadi penentu keberhasilan suatu proses belajar mengajar. Dalam proses pembelajaran ini guru mengemban tugas penyampaian materi pelajaran kepada siswa melalui interaksi dan komunikasi. Dengan demikian, aspek keberhasilan dalam pembelajaran tersebut sangatlah ditentukan kelancaran dalam interaksi komunikasi guru dengan siswa. Kurang efektifnya komunikasi akan berdampak terhadap pesan yang disampaikan oleh guru kepada siswa.

Sejalan dengan penjelasan tersebut, Naim (2011) mengemukakan bahwa komunikasi berperan penting dalam kehidupan manusia. Sebagian besar kehidupan manusia dalam bingkai kokunikasi. Manusia tidak akan menjadi makhluk yang sempurna tanpa komunikasi. Dengan komunikasilah manusia dapat menjalani hidup secara dinamis, aktif, dan terus mencapai berbagai perkembangan dan kemajuan hidupnya.

Salah satu capaian perkembangan dan kemajuan kehidupan manusia diperoleh melalui pendidikan yang tidak bisa pula dipisahkan dari komunikasi. Pendidikan sepenuhnya dibangun oleh komunikasi karena pendidikan berkaitan dengan transmisi pengetahuan kepada orang lain atau antara guru kepada siswa.

Sumantri (2015) menjelaskan bahwa proses pendidikan dapat berhasil apabila proses komunikasi berjalan dengan baik. Proses komunikasi ini berjalan sesuai tahapan gagasan dan ide menjadi pembahasan antara komunikator dengan komunikan yang mendorong terbangunnya pemahaman atas informasi atau segala sesuatu hal menjadi pokok pembahasan yang mengarah pada kesatuan pendapat. Oleh karena itulah dalam pelbagai organisasi dapat tercapai optimal bila komunikasinya terbangun dengan lancar.

Komunikasi pendidikan guru Madrasah Ibtidaiyah saat ini diperhadapkan dengan kompleksitas yang menaraik karena proses pembelajaran harus dilakukan secara daring (dalam jaringan). Hal ini dilakukan sebagai konsekuensi faktual menyebarnya Covid-19. Diperkirakan sepanjang tahun 2021 ke depan pembelajaran daring masih akan dilakukan sebagai tindakan perlindungan terhadap guru dan siswa. Oleh karena itu, guru sangat penting memiliki pemahaman yang baik berkaitan tentang komunikasi pendidikan untuk memperkaya proses pembelajaran yang dilakukan secara daring. Berkaitan dengan hal tersebut penulis tertarik melakukan kajian teoritis komunikasi pendidikan guru Madrasah Ibtidaiyah (MI) Dalam Jaringan (Daring). Kerangka pemahaman teoritik berkaitan dengan komunikasi pendidikan sangat penting dikaji dan dipelajari untuk memaksimalkan proses pembelajaran yang dilakukan.

\section{Rumusan Masalah}

Berdasarkan pendahuluan di atas, maka rumusan masalah penulisan ini, yaitu; "Bagaimanakah deskripsi teoritik komunikasi pendidikan guru Madrasah Ibtidaiyah Dalam Jaringan (Daring)?"

\section{Pembahasan}

Komunikasi pendidikan tidak bisa dilepaskan dari teori komunikasi secara umum. Hal ini menunjukkan bahwa ilmu komunikasi bersifat sangat umum dan merupakan kebutuhan utama dalam hajat hidup manusia, terutama dalam menyelenggarakan pendidikan. Dengan demikian, untuk memiliki pemahaman berkaitan dengan rumusan masalah penulisan ini, maka diuraikan beberapa komponen penting pembahasan komunikasi pendidikan sebagai berikut.

\subsection{Hakikat Komunikasi Pendidikan}

Suatu komunikasi terbangun melibatkan dua orang atau lebih dalam kesamaan makna atas apa yang dikomunikasikan. Secara teoritik dapat diuraikan beberapa pendapat berkaitan dengan komunikasi sebagai berikut.

Mufid (2005) mengemukakan bahwa komunikasi sebagai proses penyampaian suatu pesan. Pesan ini berasal dari sender (pengirim) ke receiver (penerima) yang berlangsung melalui channel atau medium yang dapat pula mengalami gangguan tertentu. Dengan demikian, komunikasi merupakan suatu kesengajaan penyampaian pesan antara pemberi pesan kepada penerima. Dalam proses komunikasi yang berlangsung pula dapat terjadi gangguan.

Defenisi selanjutnya dikemukakan oleh Edward (Widjaja, 2000) bahwa komunikasi sebagai proses menyampaikan gagasan dan pesan menggunakan lambang-lambang tertentu. Lambang ini 
mengandung arti melalui penyampai pesan kepada penerima pesan. Konteks pesan dalam penjelasan ini ialah penyampaian amanah menggunakan komunikasi secara langsung.

Baslon dan Steiner (Reed, 2005) mengemukakan komunikasi sebagai proses menyampaikan suatu informasi pesan atau ide perasaan. Komunikasi juag merupakan keterampilan dan lain-lain menggunakan simbol, kata-kata, menggunakan gambar, juga dalam bentuk tulisan dan lain sebagainya.

Berdasarkan penjelasan beberapa defenisi tersebut di atas disimpulkan bahwa komunikasi merupakan suatu proses dimana informasi disampaikan menggunakan berbagai sarana, simbol,-simbol, kata-kata kepada penerima suatu pesan. Komunikasi terbangun untuk mencapai kesepahaman makna dengan tujuan keterjalinan komunikasi dengan baik. Komunikasi dapat dipandang sebagai tukar informasi bagi pelaku komunikasi mencapai keterhubungan simbolik yang bertujuan mengubah persepsi tentang gagasan yang disampaikan. Ada semacam saling pengaruh timbal balik dalam proses komunikasi.

Pendidikan sebagai proses membina manusia merupakan suatu proses kompleks yang menjadikan komunikasi sebagai instrumen utama. Dengan istilah lain, pendidikan tidak bisa berjalan dengan baik tanpa komunikasi dibangun secara efektif. Untuk itulah komponen pengelola pendidikan sangat penting memahami komunikasi pendidikan sebagai dasar pengelolaan pendidikan yang baik.

Defenisi komunikasi yang telah diuraikan di atas dapat memberikan gambaran berkaitan dengan hakikat komunikasi pendidikan. Gufron (2016) menjelaskan komunikasi pendidikan terbangun dalam situasi dan suasana belajar. Lebih lanjut dijelaskannya bahwa secara istilah komunikasi pendidikan dipahami sebagai tindakan yang dapat berkontribusi dalam pemahaman maupun secara praktis individu dalam dunia pendidikan. Defenisi ini sangat sederhana karena seluruh proses pengelolaan pendidikan sesungguhnya melibatkan komunikasi verbal mapun tertulis.

Berdasarkan penjelasan tersebut dapat dipahami bahwa hakikan komunikasi pendidikan merupakan proses transmisi informasi yang melibatkan seluruh komponen pendidikan dalam mengelola pendidikan. Dalam konteks pembelajara komunikas pendidikan berperan penting dalam konteks transfer ilmu pengetahuan dari guru kepada peserta didiknya. Komunikasi pendidikan juga tentunya sangat berperan dalam konteks pembinaan yang dilakukan oleh guru dalam memfasilitasi pembelajaran siswa. Dengan demikian, komunoikasi pendidikan merupakan instrumen yang penting untuk dipahami dan dimaksimalkan oleh guru dalam pembelajaran.

\subsection{Fungsi Komunikasi Pendidikan}

Komunikasi menjadi instrumen fundamental yang menjadi kunci keberlangsungan proses pendidikan. Dengan demikian, komunikasi haruslah secara efektif terbangun antara pengelola pendidikan dengan tenaga pendidikan maupun dengan masyarakat. Lebih spesifik lagi komunikasi dengan guru dan siswa memiliki dinamika tersendiri sehingga membutuhkan keahlian guru mengelola fungsi komunikasi dengan siswanya dengan baik untuk mencapai tujuan pembelajaran. Chotimah (2015) menjelaskan beberapa fungsi komunikasi dalam dunia pendidikan sebagai berikut.

Pertama, fungsi sosial. Komunikasi berfungsi sosial menunjukan komunikasi sebagai sara pembangun diri, mengaktualisasi diri serta menjadi wahana memperoleh kebahagiaan. Lebih lanjut dijelaskan bahwa komunikasi secara sosial sangat penting di lingkungan dunia pendidikan siswa untuk menghidupkan interaksi guru dengan siswa maupun siswa dengan siswa. Sekolah merupakan ekosistem lingkungan yang terkoneksi secara sosial sehingga seseorang tanpa komunikasi akan mengalami kesulitan membangun diri maupun bersosialisasi diri dengan orang lain di lingkungan sekolah. Dengan demikian, guru sangat penting memiliki pemahaman komunikasi sosial ini sehingga mampu mengelola keragaman sosial dan mampu membangun koneksi melalui komunikasi dengan banyak karakter siswa dari berbagai latar belakang sosial.

Kedua, fungsi ekspresif. Fungsi komunikasi secara ekspresif berkaitan dengan fungsi komunikasi yang telah diuraikan terdahulu. Dengan kata lain, komunikasi pada aspek fungsi ini dapat dilakukan secara personal maupun kelompok. Oleh karena itu, guru yang memiliki kecakapan komunikasi yang baik secara ekspresif memungkinkan mampu mengelola emosi atau perasaan peserta didik dengan baik. Guru mampu membimbing siswa untuk mengungkapkan masalahnya tanpa harus memendam. 
Saat ini banyak siswa terjebak dalam masalah kenakalan remaja maupun tawuran yang menunjukkan aspek komunikasi secara sosial terputus sehingga siswa terjerumus pada ekspresi kekerasan dan bullyng yang merugikan dirinya maupun citra pendidikan. Fakta ini menunjukkan bahwa suasana belajar harus menjadi ruang ekspresif siswa mengungkapkan emosi-emosinya serta mampu menemukan emosi empatik dirinya pada orang lain. Guru dapat menggunakan komunikasi ekspresif ini untuk menanamkan sikap peduli, gembira, sedih dan lain sebagainya yang harus dikomunikasikan secara verbal maupun nonverbal melalui sikap yang santun.

Ketiga, fungsi secara ritual. Aspek fungsi ini berfungsi untuk mentransmisi nilai-nilai keagamaan. Selain itu juga terdapat transmisi nilai tradisi maupun budaya berbasis komunitas di dalamnya. Fungsi komunikasi ini dominan berfungsi di lingkungan ketika diadakan kegiatankegiatan kegamaan maupun pelepasan siswa sehingga menjadi momentum penguatan keagamaan dan nilai-nilai luhur bagi siswa, termasuk penguatan spritual bagi siswa menghadapi momen seperti ujian Nasional.

Keempat, fungsi instrumental. Fungsi ini memiliki beberapa tujuan yang secara umum berkaitan dengan komunikasi sebagai sarana untuk menginformasikan, mengajar dan mendorong, mengubah sikap dan keyakinan. Selain itu komunikasi dalam konteks ini juga mengubah perilaku atau menggerakkan. Oleh karena itulah, fungsi instrumen ini mengandung persuasi bagi guru mengirimkan pesan kepada siswa sebagai pendengarnya. Guru haruslah menyampaikan pesan sesuai fakta atau informasi yang diasampaikan guru haruslah akurat yang mengandung nilai edukasi bagi siswa.

\subsection{Unsur-Unsur Komunikasi Pendidikan}

Komunikas pendidikan tidak berlangsung melalui satu orang saja, namun lebih da itu terdapat banyak unsur yang terlibat dalam suatu peristiwa komunikasi pendidikan. Oleh karena itu, pemahaman guru tentang fungsi-fungsi komunikasi pendidikan tersebut di atas melibatkan berbagai unsur komunikasi pendidikan.

Pertama, suatu komunikasi pendidikan melibatkan komunikator. Dalam hal ini guru merupakan komunikator utama pendidikan yang harus memiliki kemampuan dasar komunikasi yang baik. Hal ini akan sangat membantu berjalannya proses pembelajaran di sekolah. Dengan demikian, guru berfungsi sebagai encoder atau figur yang memformulasikan pesan kepada siswa. Pesan ini berupa berbagai topik pembelajaran yang menjadi pembahasan yang disajikan melalui materi pembelajaran. Siswa dalam kontek penerimaan pesan ialah sebagai decoder yang menerjemahkan maksud dan konteks pesan yang mereka terima dalam pembelajaran.

Formulasi pesan dan penyampaian guru membuat siswa berhadapan dengan kompleksitas di luar pengetahuan mereka, sehingga membutuhkan waktu dalam menyerap isis pesan yang dimaksudkan oleh guru. Pada titik ini guru sekali lagi diuji untuk mempu menyampaikan pesan secara lugas sesuai dengan kapasitas dan kemampuan siswa dalam pembelajaran.

Berkaitan dengan hal ini, Efendi (1996) menjelaskan bahwa suatu persamaan makna berkantung pada komunikatornya, dalam konteks pembelajaran sangat tergantung sebagai komunikator. Lebih lanjut dia menjelaskan bahwa terdapat beberapa syarat bagi komunikator ini meliputi; a) memiliki kredibilitas yang tinggi bagi komunikannya; b) komunikator harus memiliki kemampuan berkomunikasi; c) mempunyai pengetahuan yang luas; d) komunikator harus memiliki sikap; dan d) komunikator memiliki daya tarik, dalam arti memiliki kemampuan untuk melakukan perubahan sikap atau perubahan pengetahuan pada diri komunikan.

Kedua, unsur pesan. Suatu komunikasi mengandung pesan sebagai tujuan penyampaiannya. Pesan yang dikirim bisa dalam bentuk verbal dapat berupa tertulis maupun lisan. Pesan verbal tertulis biasanya dalam bentuk buku dan surat kabar dan lain sebagainya. Selain itu, pesan juga bisa dalam bentuk nonverbal seperti isyarat, ekspresi dan nada suara. Widjaya (1887) menjelaskan beberapa bentuk pesan sebagai berikut.

a. Pesan informatif, yang memberi pesan atau keterangan kepada komunikan mengambil kesimpulan sendiri terhadapnya. Dengan demikian, guru dalam konteks komunikasi ini dapat mengelola pesan yang lugas sehingga mudah diolah oleh siswa dan siswa mampu mengambil kesimpulan terhadap pesan yang dikemukakan oleh guru. 
b. Pesan persuasif, bentuk pesan yang berisi bujukan. Tujuan bentuk pesan ini yaitu menstimulus pengertian dan membentuk kesadaran penerima pesan sehingga dapat mengambil sikap untuk perubahan dirinya atas pilihan dan kehendak dirinya sendiri. Konteks pesan semacam ini dapat digunakan oleh guru dalam situasi beajar. Apalagi pada kasusu anak Madrasah Ibtidaiyah, bujukan dapat efektif secara persuasif untuk membuju anak belajar. Tentunya hal ini dilakukan dengan pelbagai pendekatan yang lebih sesuai dengan dunia siswa dalam mengikuti proses pembelajaran.

c. Pesan koersif, bentuk pesan ini diberikan melalui bentuk sanksi tertentu. Secara umum dikenal dengan bentuk agitasi yang menekankan hal tertentu untuk menimbulkan teknan batin maupun psikologis. Dilihat dari konteksnya, jenis pesan semacam ini tidaklah cocok dengan dunia anak Madrasah Ibtidaiyah. Sanksi hanya akan memberikan beban psikologis pada anak sehingga anak dapat tumbuh dengan perasaan takut terhadap dunia pembelajaran sebagai momok yang menakutkan. Meskipun harus diberikan bentuk sanksi tertentu, untuk anak Madrasah Ibtidaiyah haruslah sanksi dalam bentuk aksi membersihkan dan lain-lain yang dapat bermanfaat secara langsung pada diri siswa.

Ketiga, unsur media. Komunikasi menggunakan media sebagai alat. Setiap komunikator membutuhkan alat ini sebagai penyampai pesan informatif kepada komunikan atau penerima pesan. Oleh karena itu, sarana yang digunakan dapat memberikan informasi timbalbalik dari penerima pesan kepada orang yang memberikan komunikasi.

Media dalam konteks ini menjadi perantara atau penyalur informasi yang disampaikan. Dalam proses pembelajaran guru membutuhkan berbagai media pembelajaran, sebut saja media visual menggunakan video maupun gambar. Media lainnya seperti papan tulis maupun media audio. Semua jenis media ini dapat disesuaikan dengan kebutuhan pembelajaran yang sesuai dengan minat dan kondisi siswa dalam pembelajaran. Saat ini, di tengah pembelajaran pada Madrasah Ibtidaiyah yang dilakukan secara daring, jenis media utama yang dilakukan menggunakan teknologi berbasis android. Guru maupun siswa dituntut mampu mengefektifkan komunikasi dalam memproses dan menyampaikan pesan sehingga mudah diterima dan dipahami.

Keempat, unsur penerima. Pihak yang menjadi sasaran dalam komunikasi adalah pihak penerima. Unsur penerima ini bisa bersifat satu orang maupun lebih, bisa pula dalam bentuk kelompok, bahkan partai maupun negara tertentu. Unsur penerima dalam istilah komunikasi disebut pula sebagai khalayak, komunikan, sasaran. Pada proses komunikasi dapat dipahami bahwa sesungguhnya keberadaan penerima merupakan akibat adanya sumber penyampai pesan. Dalam artian eksistensi penerima dapat diketahui jika diketahui sumber pemberi pesan.

Cangara (2008) menjelaskan bahwa unsur penerima dalam komunikasi merupakan elemen penting karena menjadi sasaran dalam suatu peristiwa komunikasi. Apabila suatu pesan tidak diterima hanya akan menimbulkan berbagai macam masalah yang sering kali menuntut banyak perubahan pada sumber pesan, bentuk pesan, maupun saluran atau media yang digunakan. Dengan demikian, komunikasi yang efektif haruslah ditunjang dengan komunikator dan komunikan. Komunikan dituntut harus mampu mendengarkan dan memahami pesan yang tersampaikan. Begitu pula sebalinya, dalam konteks komunikasi komunikator harus mampu mengelolah dan menyampaikan pesan yang baik.

Kelima, unsur efek. Setiap komunikasi yang berlangsung memberikan efek tertentu. Dalam dunia pendidikan, komunikasi guru haruslah mampu memberikan efek stimulus terhadap siswa. Berkaitan dengan efek komunikasi ini, Cangara (2008) menjelaskan bahwa efek yang timbul dari komunikasi berkaitan dengan perbedaan yang terpikirkan, sesuatu yang dapat dirasakan dan mampu dilakukan oleh penerima pesan. Pola pengaruh ini dijelaskannya dapat terjadi pada aspek pengetahuan, aspek sikap dan tingkah laku seseorang. Sehingga pengaruh ini bisa diartikan sebagai perubahan atau sebentuk penguatan keyakinan pada aspek sikap dan tindakan seseorang sebagai akibat pengirim pesan.

Lebih lanjut, Cangara (2008) menjelaskan bahwa berbagai dampak tersebut dapat diklasifikasikan menurut kadarnya, meliputi; 
a. Dampak kognisi. Dampak ini ditimbulkan komunikasi melalui komunikator yang memberikan pengetahuan dan meningkatkan intelektualitas komunikas. Sejalan dengan hal ini, dalam dunia pendidikan komunikasi berperan digunakan untuk menstimulus pengetahuan siswa Madrasah Ibtidaiyah.

Dampak ini akan berkontribusi pada aspek perkembangan kognisi siswa Madrasah Ibtidaiyah berupa kemampuan mentalitas belajar, kemampuan menalar, berpikir, dan kemampuan berbahasa siswa. Komunikasi pendidikan yang efektif dari guru harus mampu memberikan dampak tersebut. Proses untuk mencapai dampak itu haruslah berkesinambungan dalam lingkungan pembelajaran yang memadai karena sasaran utamanya adalah kecerdasan dan pengetahuan siswa. Guru dalam berkomunikasi harus mengukur terlebih dahulu sampai dimana kemampuan siswa yang terlibat dalam proses pembelajaran jangan sampai pesan komunikasi berisi materi pelajaran jauh di atas kemampuan siswa, sehingga dapat berdampak buruk terhadap perkembangan kognisis siswa.

b. Dampak afektif. Dampak ini memiliki posisi lebih tinggi dari rasa ingin tahu komunikan karena tergerak hatinya. Sehingga pola komunikasi dapat menimbulkan suatu perasaan tertentu sebagai efeknya. Misalnya perasaan terharu, empatik, sedih, merasakan kegembiraan.

Komunikasi pendidikan yang dilakukan oleh guru pada Madrasah Ibtidaiyah harus menyentuh aspek afektif siswa. Di tengah kehidupan sosial yang terdampak pandemik hari ini, afektif siswa harus dikemas ke arah empatik berbagi, melindungi diri adalah melindungi orang lain, serta mampu membahu orang teman sejawat yang kurang mampu. Komunikasi guru yang dilakukan dalam pembelajaran sejatinya menanamkan narasi pengentasan pandemik melalui peningkatan kesadaran dan perlindungan kepada sesama manusia.

Guru haruslah menekankan aspek-aspek berpikir konkret. Hal ini dimaksudkan menjangkau proses berpikir konkret siswa karena usia siswa pada tingkat Madrasah Ibtidaiyah ialah usia yang sudah berpikir konkret. Anak-anak belum bisa berpikir abstrak sehingga pola komunikasi guru haruslah disesuaikan. Dengan demikian, guru dalam berkomunikasi perlu menggunakan pelbagai logika konkret yang bersifat fisik. Proses selanjutnya diharapkan siswa dapat menyusun maksud atau makna dari contoh yang diberikan dalam pembelajaran daring.

c. Dampak behavioral (konatif). Dampak ini merupakan capaian tertinggi kadarnya dalam komunikasi. Bentuk dampaknya berupa perilaku, tindakan ataupun kegiatan dari kuminikam setelah menerima pesan dari komunikasi yang dilakukan.

Dampak ini akan melahirkan ciri-ciri tertentu pada siswa seperti kemampuan untuk belajar dari bercermin pada sikap, tindakan dan tingkah laku orang lain. Guru harus mampu membangun kemampuan siswa meniru atau mengidolakan tokoh favoritnya, tentunya mencakup sikap kekaguman yang postif. Siswa yang berhasil diarahkan mencapai ini akan mampu memiliki kecenderungan identifikasi berbagai hal dalam kehidupannya.

Berdasarkan penjelasan tersebut, dapat disimpulkan bahwa unsur komunikasi pendidikan meliputi banyak aspek yang meliputi unsur adanya komunikator, adanya pesan, adanya adanya media, adanya penerima, adanya efek. Dalam hal efek komunikasi harus memberikan semacam daya kejut berupa dampak kognisi, dampak afektif, dan dampak behavioral pada siswa. Dampak yang dihasilkan dari komunikasi pendidikan yang dikelolah guru dicapai secara bertahap seiring perkembangan siswa.

\subsection{Kedudukan Guru dalam Komunikasi Pendidikan}

Guru memainkan peran kunci dalam dunia pendidikan untuk mencapai keberhasilan pembelajaran. Sutirna (2013) mengemukakan keberhasilan siswa dapat dicapai dengan peranan guru sebagai pembimbing dalam proses belajar mengajar. Untuk mencapai hal tersebut guru memainkan beberapa hal penting meliputi; a) guru mengarahkan siswa untuk lebih mandiri untuk mengembangkan potensinya; b) guru harus memerlakukan siswa secara baik dan wajar; c) guru memperlakukan siswa dengan kerahaman dan rendah hati yang menyenangkan; d) guru perlu memiliki penampilan menarik di depan kelas secara ikhlas; e) dalam proses pembelajara guru harus menerima siswa apa adanya berdasarkan latar sosial budaya masing-masing; f) guru harus menyadari 
bahwasanya penguasaan siswa bukanlah tujuan mengajar, melainkan melakukan pengembangan potensi siswa secara optimal.

Capain tersebut tidak bisa dicapai tanpa melibatkan komunikas pendidikan secara efisien. Oleh karena itu, dalam mengemban tugasnya, guru memainkan banyak peranan penting dalam komunikasi. Kedudukan peran guru dalam komunikasi pendidikan ini dapat dijelaskan sebagai berikut.

a. Guru sebagai pembicara. Dalam setiap pembelajaran, guru merupakan pembicara untuk memantik pembelajaran. Dalam konteks komunikasinya, Richmond (Iriantara, 2013) mengemukakan guru perlu meningkatkan efektivitas komunikasi, meliputi beberapa hal sebagai berikut.

Pertama, waktu yang tersedia harus dialokasikan untuk penyampaian materi utama. Waktu juga perlu dibagi untul pengulangan materi dengan berbagai tanya jawab, guru memberikan contoh, dan bila dibutuhkan pelru diisi selingan humor.

Kedua, siswa dibantu oleh guru dalam memahami dan mencatat pokok materi dalam pembelajaran. Hal ini didahului dengan penyajian materi dengan cara yang membuat siswa lebih mudah memahami, misalnya penyajian poin-poin penting, gambar, dan bagan materi pembelajaran.

Ketiga, penyampaian cerama oleh guru dilakukan dengan suasana keakraban. Guru perlu menyapa siswa baik dengan menyebutkan nama, melakukan tanya jawab dengan siswa, serta menggunakan kata-kata yang menunjukkan kedekatan yang lebih persuasi. Bentuk cerama harus lebih santai lagi dengan menggunakan berbagai contoh yang mudah ditangkap oleh siswa.

b. Guru sebagai moderator. Dalam situasi tertentu dalam pembelajaran, guru harus menjadi pendengar yang baik bagi dinamika forum siswa. Sehingga komunikasi antar siswa dapat lebih hidup melalui tukar pendapat secara sederhana. Berkaitan dengan hal ini, Iriantara (2013) menjelaskan bahwa guru harus menjadi moderator yang efektif.

Lebih lanjut dia menjelaskan untuk menjadi moderator yang efektif ini, dengan mengutip hasil kajian Stanford University, bahwa guru harus memiliki beberapa keterampilan yaitu; 1) guru dapat mengajukan pertanyaan kepada siswanya; 2) dalam menjalankan posisinya sebagai moderator guru haruslah mampu mendorong siswa berpartisipasi aktif dalam pembelajaran; 3 ) guru mendorong siswa memahami dan mendalami materi belajar dengan contoh-contoh sederhana; 4) guru menggunakan pertanyaan yang mendorong penalaran tingkat tinggi; 5) mampu memfasilitasi berbagai pertanyaan dan komentar siswa; 6) mampu menggunakan media komunikasi nonverbal secara efektif, dan 7) terampil dalam berbagai teknik interaksi guna mencegah kebosanan.

c. Guru sebagai pembimbing. Iriantara (2013) menjelaskan bahwa dalam pembelajaran yang menekankan aspek psikomotor, guru berperan menjadi pembimbing. Ketika membelajarkan kemampuan psikomotoris, guru memfasilitasi siswa harus berlatih sampai para siswa benarbenar menguasai keterampilan tersebut. Guru harus berpandai-pandai dalam membuat variasi latihan sehingga siswa tidak merasa bosan.

d. Guru sebagai manajer. Guru sebagai pengelola atau manager atau organisator dalam pembelajaran. Dalam peranannya ini guru memiliki tugas dan kewajiban untuk mengelola pembelajaran dengan baik. Pengelolaan dimulai dari perencanaan, pelaksanaan termasuk juga melakukan evaluasi agar terorganisir dengan baik. Pengelolaan pembelajaran ini akan membawa proses pembelajaran terlaksana dengan lancar yang dapat memudahkan dalam komunikasi pencapaian tujuan pembelajaran (Iriantara, 2013)

Berdasarkan penjelasan tersebut dapat disimpulkan bahwa kedudukan guru dalam komunikasi pendidikan merupakan instrumen kunci untuk mencapai tujuan pembelajaran. Guru memainkan peran komunikasi secara efektif melalui banyak peran yang meliputi perannya sebagai pembicara, sebagai moderator dalam pembelajaran., sebagai pembimbing untuk menuntun siswa, dan berperan sebagai manajer karena guru menjadi pengelola atau organisator seluruh proses pembelajaran. 


\section{Kesimpulan}

Berdasarkan uraian pembahasan di atas, dapat dirumuskan kesimpulan sebagai berikut.

Pendidikan dapat berhasil jika didudkung dengan komunikasi yang efektif. Proses komunikasi dalam pendidikan terbangun melalui komunikator dengan komunikan. Guru sebagai salah satu komunikator dalam komunikasi sangat menentukan keberhasilan pembelajaran. Di tengah pandemik, komunikasi pendidikan sangat penting sebagai instrumen satu-satunya dalam pembelajaran daring. Dengan demikian, pembelajaran di tengah pandemik sangat ditentukan oleh pola komunikais guru dalam pembelajaran.

Guru perlu memiliki kemampuan komunikasi yang mumpuni melalui pendalaman materi komunikasi pendidikan dengan mempelajari hakikat komunikasi pendidikan, guru perlu memahami fungsi dan unsur komunikasi pendidikan. Selain itu, sangat penting pula bagi guru memahami kedudukannya dalam konteks komunikasi pendidikan untuk memaksimalkan pembelajaran. Guru memainkan peran komunikasi secara efektif melalui banyak peran yang meliputi perannya sebagai pembicara, sebagai moderator dalam pembelajaran., sebagai pembimbing untuk menuntun siswa, dan berperan sebagai manajer karena guru menjadi pengelola atau organisator seluruh proses pembelajaran. 


\section{DAFTAR PUSTAKA}

Cangara, Hafied. 2008. Pengantar Ilmu Komunikasi. Jakarta: PT Raja Grafindo Persada.

Chotimah, Chusnul. 2015. Komunikasi Pendidikan. Tulungagung: IAIN Tulungagung Press.

Effendi. 1996. Kepemimpinan dan Komunikasi. Yogyakarta: Al-Amin Press.

Gufron, Moh. 2016. Komunikasi Pendidikan. Yogyakarta: Kalimedia.

Iriantara, Yosal. 2013. Komunikasi Pendidikan. Bandung: Remaja Rosdakarya.

Mufid, Muhammad. 2005. Komunikasi dan Regulasi Penyiaran. Jakarta: Kencana.

Naim, Ngainun. 2011. Dasar-Dasar Komunikasi Pendidikan. Jogjakarta: Ar-Ruzz Media.

Reed H dkk. 2005. Taksonomi Konsep Komunikasi, Cetakan kedua. Surabaya: Papyrus.

Sumantri, Mohamad Syarif. 2015. Strategi Pembelajaran: Teori dan Praktik di Tingkat Pendidikan Dasar. Jakarta: PT RajaGrafindo Persada.

Sanjaya, Wina. 2006. Strategi Pembelajaran. Jakarta: Prenademedia Group.

Sutirna. 2013. Bimbingan dan Konseling. Yokyakarta: Andi Offset.

Widjaya, H.A.W. 1997. Komunikasi dan Hubungan Masyarakat. Jakarta: PT Bumi Aksara.

Widjaja, H.A. W. 2000. Ilmu Komunikasi Pengantar Studi. Jakarta: PT. Rineka Cipta. 